\title{
Reduction Spermatozoa Motility and Viability on Various Local Chickens During Storage at $5^{\circ} \mathrm{C}$
}

\author{
Nu'man Hidayat $^{1}{ }^{*}$, Chomsiatun Nurul Hidayah ${ }^{2}$ and Aras Prasetiyo Nugroho ${ }^{2}$ \\ ${ }^{1}$ Laboratory of Poultry Production, Faculty of Animal Science, Jenderal Soedirman University \\ ${ }^{2}$ Laboratory of Animal Physiology and Reproduction, Faculty of Animal Science, Jenderal Soedirman University \\ *Corresponding author email: hidayatn24@unsoed.ac.id
}

\begin{abstract}
The research compared the changes motility and viability of sperm from various local chickens during storage at $5^{\circ} \mathrm{C}$ for 72 hours. Semen was collected every three days using the dorsal-abdominal massage from twelve chickens consisting of Kedu, Sentul and Pelung chicken. semen was diluted in extender contains $90 \%$ lactate ringer and $10 \%$ egg yolk extender with $0.025 \%$ sodium dodecyl sulfate and $2 \%$ vitamin $E$ (LREYSE). Sperm motility and viability was observed every 12 hours and the measurements were made up to 72 hours of storage. Complete random design repeated measurement with 4 replications was used in this study. One-way analysis of variance was used to analyze the data and followed by Duncan's Multiple Range Test. The results showed sperm motility declined and sperm viability reduced during storage for all breeds. The significant declined of motility between breeds were only observed at 60 and 72 hours and the reduced viability between breeds was observed at 72 hours of storage. The declined sperm motility for Kedu chicken $(31.59 \pm 3.26 \%$ and $75.36 \pm 1.25 \%)$ and Pelung chicken $(36.11 \pm 4.05 \%$ and $75.83 \pm 5.34 \%)$ were significantly lower $(p<0.05)$ than Sentul Chicken $(50.39 \pm 2.60 \%$ and $95.00 \pm 5.00 \%$ ) at 60 and 72 hours of storage respectively, while the decline sperm viability of Kedu chicken $(57.59 \pm 3.64 \%)$ and Pelung chicken $(54.39 \pm 5.73 \%)$ was significantly lower $(p<0.05)$ than Sentul Chicken $(90.30 \pm 9.70 \%)$ after 72 hours storage. It can be concluded that the reduction sperm motility and viability of Kedu and Pelung chicken is lower than Sentul chicken which are stored at $5^{\circ} \mathrm{C}$ for 72 hours.
\end{abstract}

Keywords: decreasing sperm motility, decreasing sperm viability, local chicken

Absrak. Penelitian ini bertujuan untuk membandingkan perubahan motilitas dan viabilitas spermatozoa berbagai rumpun ayam lokal yang dipreservasi pada suhu $5^{\circ} \mathrm{C}$ selama 72 jam. Semen dikoleksi setiap tiga hari sekali dengan metode dorsal-abdominal massage. Semen berasal dari 12 ekor ayam yang terdiri dari ayam Kedu, Sentul dan Pelung. Semen diencerkan dalam pengencer yang terdiri dari $90 \%$ ringer laktat dan $10 \%$ kuing telur dengan penambahan $0,025 \%$ sodium dodecyl sulfate dan $2 \%$ vitamin E (RLKTSE). Motilitas dan viabilitas spermatozoa diamati setiap 12 jam dan pengamatan dilakukan sampai 72 jam penyimpanan. Rancangan Acak Lengkap dengan 4 kali ulangan digunakan dalam penelitian ini. Data dianalisis menggunakan one-way ANOVA dan dilanjutkan dengan Uji Duncan. Hasil penelitian menunjukkan motilitas dan viabilitas spermatozoa pada berbagai ayam lokal mengalami penurunan selama peyimpanan. Penurunan motilitas spermatozoa yang signifikan diantara ayam lokal terjadi pada 60 dan 72 jam penyimpanan, sedangkan penurunan viabilitas spermatozoa yang signifikan diantara ayam lokal terjadi pada 72 jam penyimpanan. Penurunan motilitas spermatozoa ayam Kedu $(31,59 \pm 3,26 \%$ dan $75,36 \pm 1,25 \%)$ dan ayam Pelung $(36,11 \pm 4,05 \%$ dan $75,83 \pm 5,34 \%)$ secara signifikan lebih rendah $(p<0,05)$ dibandingkan ayam Sentul $(50,39 \pm 2,60 \%$ dan $95,00 \pm 5,00 \%)$ pada 60 dan 72 jam penyimpanan berturut-turut, sedangkan penurunan viabilitas spermatozoa ayam Kedu $(57,59 \pm 3,64 \%)$ dan ayam Pelung $(54,39 \pm 5,73 \%)$ secara signifikan lebih rendah $(p<0,05)$ dibandingkan ayam Sentul $(90,30 \pm 9,70 \%)$ pada 72 jam penyimpanan. Berdasarkan hasil penelitian dapat disimpulkan bahwa penurunan motilitas dan viabilitas spermatozoa ayam Kedu dan Pelung lebih kecil dibandingkan ayam Sentul yang disimpan pada suhu $5^{\circ} \mathrm{C}$ selama $72 \mathrm{jam}$.

Kata kunci: penurunan motilitas spermatozoa, penurunan viabilitas spermatozoa, ayam lokal

\section{Introduction}

Local chickens are one of the genetic resources in Indonesia that have the potential to be developed as a provider of national animal protein products. Local chickens on the island of
Java include Pelung, Sentul and Kedu chickens. Pelung chicken is an endemic chicken in Cianjur, West Java which is classified into the weight type with adult body weight at 52 weeks of $3.51 \pm 0.21 \mathrm{~kg}$ in males and $2.045 \pm 0.18 \mathrm{~kg}$ in 
females (Nataamijaya et al., 2003). Sentul chicken is a local chicken variety developed by the community in Ciamis Regency, West Java with an average adult body weight of $2.515 \mathrm{~kg}$ with a high daily gain $70.30 \pm 1.87 \mathrm{~g}$. Sentul chickens produces 12 to 30 eggs in one laying period or about 150 eggs/year (Sulandari et al., 2007). Kedu chicken is a local chicken develops in Kedu, Temanggung, Central Java with an adult male body weight of 1.7-2.4 kg and females around 1-1.6 $\mathrm{kg}$ and has an egg production of 200 eggs/year (Nataamijaya, 2000).

The local chickens are very potential for artificial insemination (AI). The quality of spermatozoa affects the success of $\mathrm{Al}$, so the quality must be maintained since the semen collection. The quality of spermatozoa can be maintained by suppressing the metabolic rate of spermatozoa through storage at low temperatures $\left(2-5^{\circ} \mathrm{C}\right)$. During the storage spermatozoa will experience a cold shock (cold shock). Cold shock occurs due to changes in the chain arrangement of fatty acids and proteins on the plasma membrane, causing leakage or damage to the plasma membrane selectivity, which causes ions such as calcium ions and other substrates to enter the cell freely (Martinenaite and Tavenier, 2010). Addition milk or egg yolk in a diluent reduces the effects of cold shock (Akhter et al., 2010; Andrabi et al., 2008). Spermatozoa will continue their metabolism during storage and produce free radicals. The free radicals are reactive and dangerous for the survival of spermatozoa, so that they will reduce the quality of semen during storage. Therefore, Research on declining spermatozoa motility and viability of various types of local chickens during storage is very important to know the best quality resistance of semen and determine how long storage should be done before use for artificial insemination.

\section{Materials and Metodhs}

\section{Animals}

The Experiments were performed in Teaching and Experimental Farm and the Poultry Production Laboratory, Animal Science Faculty, Jenderal Soedirman University. Three types of local chickens (Kedu, Sentul, and Pelung) 3 each strain age 1.5 years old were used in this study. All chickens were given commercial feed and water ad libitum. Semen from all of the chickens were routinely collected every three days with 4 replications.

\section{Extender preparation}

The basic extender (LREYSE) adopted from Hidayat et al. (2016) used in this research (Table 1). The solution homogenized with the stirrer for 5 minutes and then centrifuged at $3000 \mathrm{rpm}$ for 10 minutes. Supernatants was used as semen extender.

Tabel 1. Composition of semen extender

\begin{tabular}{lc}
\hline Materials & Concentration \\
\hline Lactate Ringers & $90 \%$ \\
Egg Yolk & $10 \%$ \\
SDS & $0.025 \%$ \\
Vitamin E & $2 \%$ \\
Penisilin $\left(I U \mathrm{~mL}^{-1}\right)$ & 1000 \\
Streptomisin $\left(\mathrm{mg} \mathrm{mL}^{-1}\right)$ & 1 \\
$\mathrm{pH}^{*}$ & 6.8 \\
\hline
\end{tabular}

*pH was adjusted with tris hydroxymethyl aminomethane, SDS= sodium dodecyl sulfate. 


\section{Semen collection, Chilling, and Evaluation}

Semen was collected from 3 chickens of each type (Pelung, Sentul and Kedu) and repeated four times at three-day intervals using the massage method. Semen collection was done by massaging the lower part of the pubic bone until the male responded by producing the papillae. After the papillae appeared, the lower part of the pubic bone was pressed using right and left index fingers so the that semen comes out until the ejaculation reflex disappeared.

Semen from each type of local chicken was diluted with LREYSE with a ratio 1:4, then stored at $5^{\circ} \mathrm{C}$ in the refrigerator. The quality of the liquid semen was evaluated every 12 hours for 72 hours of storage. Observation of percentage sperm motility was carried out by placing a drop of semen on object glass under 400x magnification (Malik et al., 2017). Observation made subjectively. The sperm viability was evaluated using eosin-nigrosin staining by placing one drop of semen and two drops of eosin-nigrosin solution on object glass observed under 400x magnification. A total of 200 spermatozoa were observed. Live spermatozoa dis not uptake the dye and dead spermatozoa uptake the dye (Arifiantini, 2012).

\section{Statisctical Analysis}

Reduction on motility and viability were showed as means \pm standard error (SE). Oneway analysis of variance (ANOVA) was used to analyze the data and followed by Duncan's Multiple Range Test to determine differences between the treatment means. Significant differences were statistically based by probability of $p<0.05$.

\section{Results and Discussion}

The results showed motility and viability of spermatozoa were not significantly different $(p>0.05)$ between the three types of local chickens (Table 2). Sperm motility of Kedu, Sentul and Pelung chickens ranged from 80$85 \%$. This result was higher than the spermatozoa motility of native chickens $77 \pm$ 4.22\% (Wiyanti et al., 2013) and broilers $74.67 \pm$ 1.45\% (Tabatabaei et al., 2010). The spermatozoa viability of the three types of local chickens was $93 \%$, almost the same as the results of research on native chickens of $92.5 \pm$ 2.37\% (Wiyanti et al., 2013).

Reduction sperm motility at 48 hours of storage in this study showed not significantly different $(p>0.05)$ between 3 types of local chicken, while the percentage motility reduction of Kedu and Pelung chickens was significantly lower $(p<0.05)$ than Sentul chicken after 60 and 72 hours of storage (Table 3 ). Table 4 showed not significantly different $(p>0.05)$ on sperm viability reduction between all groups of local chicken until 60 hours of storage. After 72 hours, sperm viability reduction of Kedu and Pelung chickens was significantly lower $(p<0.05)$ than Sentul chicken. Differences spermatozoa quality caused by the type of chicken. This is in accordance with the opinion of Siudzinska and Lukaszewicz (2008) which states that the quality of semen is strongly influenced by the species and family of birds.

Table 2. Sperm motility and viability (\%) of various local chickens before storage at $5^{\circ} \mathrm{C}$

\begin{tabular}{lccc}
\hline \multirow{2}{*}{ Characteristic } & \multicolumn{3}{c}{ Strain } \\
\cline { 2 - 4 } & Kedu & Sentul & Pelung \\
\hline Motility & $83.75 \pm 1,25^{\mathrm{a}}$ & $81.25 \pm 1.25^{\mathrm{a}}$ & $82.50 \pm 1.44^{\mathrm{a}}$ \\
Viability & $93.25 \pm 0,78^{\mathrm{a}}$ & $93.00 \pm 0.74^{\mathrm{a}}$ & $93.00 \pm 0.65^{\mathrm{a}}$ \\
\hline
\end{tabular}

Different superscripts of means \pm SE in the same row not significantly different $(p<0.05)$. 
Table 3. The percentage of decreased sperm motility (\%) of various local chickens during storage at $5^{\circ} \mathrm{C}$

\begin{tabular}{lccc}
\hline Time & & Strain & \\
\cline { 2 - 4 } (hours) & Kedu & Sentul & Pelung \\
\hline 12 & $13.42 \pm 1.42^{\mathrm{a}}$ & $12.31 \pm 0.18^{\mathrm{a}}$ & $10.57 \pm 2.81^{\mathrm{a}}$ \\
24 & $12.02 \pm 1.64^{\mathrm{a}}$ & $12.26 \pm 1.72^{\mathrm{a}}$ & $11.81 \pm 1.60^{\mathrm{a}}$ \\
36 & $13.78 \pm 2.05^{\mathrm{a}}$ & $20.03 \pm 2.36^{\mathrm{a}}$ & $20.92 \pm 3.05^{\mathrm{a}}$ \\
48 & $20.34 \pm 1.61^{\mathrm{a}}$ & $20.10 \pm 0.83^{\mathrm{a}}$ & $19.54 \pm 0.45^{\mathrm{a}}$ \\
60 & $31.59 \pm 3.26^{\mathrm{a}}$ & $50.39 \pm 2.60^{\mathrm{b}}$ & $36.11 \pm 4.05^{\mathrm{a}}$ \\
72 & $75.36 \pm 1.25^{\mathrm{a}}$ & $95.00 \pm 5.00^{\mathrm{b}}$ & $75.83 \pm 5.34^{\mathrm{a}}$ \\
\hline
\end{tabular}

Different superscripts of means $\pm S E$ in the same row significantly different $(p<0.05)$.

Table 4. The percentage of sperm viability reduction (\%) of various local chickens during storage at $5^{\circ} \mathrm{C}$

\begin{tabular}{lccc}
\hline Time & & Strain & \\
\cline { 2 - 4 } (hours) & Kedu & Sentul & Pelung \\
\hline 12 & $10.58 \pm 1.50^{\mathrm{a}}$ & $10.35 \pm 0.75^{\mathrm{a}}$ & $9.41 \pm 1.86^{\mathrm{a}}$ \\
24 & $10.61 \pm 0.86^{\mathrm{a}}$ & $10.80 \pm 1.09^{\mathrm{a}}$ & $11.43 \pm 1.24^{\mathrm{a}}$ \\
36 & $12.40 \pm 1.92^{\mathrm{a}}$ & $18.30 \pm 2.11^{\mathrm{a}}$ & $16.89 \pm 2.98^{\mathrm{a}}$ \\
48 & $18.17 \pm 1.24^{\mathrm{a}}$ & $17.11 \pm 1.69^{\mathrm{a}}$ & $15.71 \pm 1.02^{\mathrm{a}}$ \\
60 & $29.76 \pm 4.74^{\mathrm{a}}$ & $42.07 \pm 1.19^{\mathrm{a}}$ & $32.79 \pm 4.59^{\mathrm{a}}$ \\
72 & $57.59 \pm 3.64^{\mathrm{a}}$ & $90.30 \pm 9.70^{\mathrm{b}}$ & $54.39 \pm 5.73^{\mathrm{a}}$ \\
\hline
\end{tabular}

Different superscripts of means \pm SE in the same row significantly different $(p<0.05)$.

The percentage of sperm motility reduction of three types of local chicken was found $10 \%$ to $20 \%$ for 48 hours of storage, $30 \%$ to $50 \%$ after 60 hours of storage and $75 \%$ to $95 \%$ after 72 hours of storage, while the percentage of sperm viability reduction of three types of local chicken was found $10 \%$ to $40 \%$ for 60 hours of storage and $50 \%$ to $90 \%$ after 72 hours of storage. Percentage of sperm motility and viability reduction of Kedu and Pelung chicken are significantly lower $(p<0.05)$ than Sentul chicken at 72 hours of storage. Variation in percentage of sperm motility and viability reduction among types of local chicken may due to the genetic potential of individual type. There are several factors affecting sperm motility following semen dilution. Avian sperm motility may be affected by the amount of oxygen and $\mathrm{Ca}++$ ions present in semen (Parker and McDaniel, 2006). According to Situmorang (2002), the decreased spermatozoa motility and viability after cooling is due to the decrease in phospholide content and cholesterol. The function of Phospolipids is to protect spermatozoa from cold shock, while cholesterol plays an important role in maintaining the integrity of spermatozoa during the cooling process and low temperature storage.

The storage of spermatozoa at $5^{\circ} \mathrm{C}$ can cause cold shock, causing lysis of the spermatozoa membrane. Cold shock reduces spermatozoa motility as a result of the contraction of the cell membrane lipoprotein, which is larger than the semen plasma content, so that it breaks down the cell membrane lipoprotein and causes the release of vital intracellular substances which will damage the integrity of the spermatozoa cell membrane. The spermatozoa plasma membrane contains many macromolecules needed in metabolic processes and as a protection for the organelles in the cell from mechanical damage. The result of metabolism is energy in the form of ATP which is needed for the motility of the spermatozoa. Thus, damage to the cell plasma membrane will result in disruption of the energy supply and ultimately reduce the motility of spermatozoa. This is in line with the storage time which results in 
changes in the integration of the cell membrane in the form of swelling in the acrosome area of the spermatozoa. The function of the acrosome in the fertilization process is very important because it produces the enzyme hyaluronidase or zona lysine which is important for ovum breakthrough (Froman and Kirby, 2008).

\section{Conclusion}

Reduction sperm motility of Kedu and Pelung chicken is lower than Sentul chicken after 60 and 72 hours of storage at $5^{\circ} \mathrm{C}$. Semen storage should not exceed 60 hours as this will result in a drastic reduction.

\section{Acknowledgement}

The research was supported by BLU UNSOED (Kept. 122/ UN23.18/ PT.01.05/ 2020). The sincerest gratitude is attended to the Head of Research Centre and Community Service of Jenderal Soedirman University for beginner lecturer research program.

\section{References}

Akhter, S., M. S. Ansari, B. A. Rakha, S. M. H. Andrabi, M. Anwar, and N. Ullah. 2010. Effect of fructose addition in skim milk extender on the quality of liquid Nili-Ravi buffalo (Bubalus bubalis) semen. Pakistan J. Zool. 42(3): 227-231.

Andrabi, S. M. H., M. S. Ansari, N. Ullah, M. Anwar, A. Mehmood, and S. Akhter. 2008. Duck egg yolk in extender improves the freezability of buffalo bull spermatozoa. Anim. Reprod. Sci. 104: 427433.

Arifiantini, I. 2012. Teknik Koleksi dan Evaluasi Semen pada Hewan. Bogor (ID): IPB Press.

Froman, D. F. and J. D. Kirby. 2008. Male Reproduction. Di dalam: Hafez ESE, Hafez B, editor. Reproduction in Farm Animals 7th Edition. Philadelphia (US): Lippincott Williams and Willkins. Pp. 237-242.

Hidayat, N., C. Sumantri, R. Afnan, and R. I.
Arifiantini. 2016. Penentuan konsentrasi sodium dodecyl sulphate dalam pengencer ringer laktatkuning telur untuk preservasi semen ayam Pelung. J. Ked. Hewan. 10(2): 170-174.

Malik, A., R. Fauzi, M. I. Zakir, dan Sakiman. 2017. Subtitusi madu asli pengganti gliserol dalam pembekuan pada kualitas pasca-thawing spermatozoa sapi bali. Acta Veterinaria Indonesiana. 5(2): 98-104.

Martinenaite, M. and J. Tavenier. 2010. Cryonics. 3rd semester project, Final report, Roskilde University. Roskilde. International Basic Studies in Natural Sciences.

Nataamijaya, A. G. 2000. The native chicken of Indonesia. Bul. Plasma Nutfah. 6(1): 1-6.

Nataamijaya, A. G., A. R. Setioko, B. Brahmantyo, and K. Diwyanto. 2003. Performans dan karakteristik tiga galur ayam lokal (pelung, arab, sentul). Seminar Nasional Teknologi Peternakan dan Veteriner. Hal. 353-359.

Parker, H. M. and C. D. McDaniel. 2006. The immediate impact of semen diluent and rate of dilution on the sperm quality index, ATP utilization, gas exchange and ionic balance of broiler breeder sperm. International J. Poult. Sci. 85: 106-116.

Situmorang, P. 2002. The effects of inclusion of exogenous phospolipid in tris diluent containing a different level of egg yolk on the viability of bull spermatozoa. JITV. 7(3): 131-187.

Siudzinska, A. and Lukaszewicz. 2008. Effect of semen extenders and storage time on sperm morphology of four chicken breeds. J. Appl. Poult. Res. 17: 101-108.

Sulandari, S., M. S. A. Zein, S. Paryanti, T. Sartika, M. Astuti, T. Widjastuti, E. Sudjana, S. Darana, I. Setiawan, and D. Garnida. 2007. Sumberdaya Genetik Ayam Lokal Indonesia. Jakarta (ID): Pusat Penelitian Biologi Lembaga Ilmu Pengetahuan Indonesia. Hal. 45-67.

Tabatabaei, S., R. Batavani, and E. Ayen. 2011. Effects of vitamin $E$ addition to chicken semen on sperm quality during in vitro storage of semen. Vet. Res. For. 2(2): 103-111.

Wiyanti, D. C., N. Isnaini, and P. Trisunuwati. 2013. Pengaruh lama simpan semen dalam pengencer nacl fisiologis pada suhu kamar terhadap kualitas spermatozoa ayam kampung (Gallus domesticus). J. Ked. Hew. 7(1): 53-55. 